\title{
EGFR Negative
}

National Cancer Institute

\section{Source}

National Cancer Institute. EGFR Negative. NCI Thesaurus. Code C150501.

An indication that EGFR expression has not been detected in a sample. 